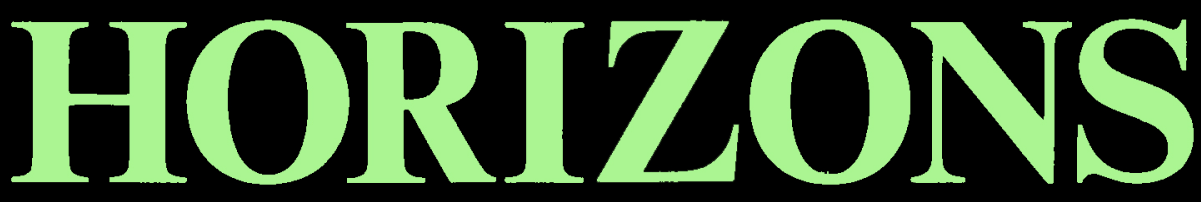

Volume 23

Spring, 1996

Number 1

\title{
ARTICLES
}

Paul K. Hennessy, C.F.C., The Infallibility of the Papal Magisterium as Presented in the Pastoral Letters of the Bishops of the United States after Vatican I

Patricia M. McDonald, S.H.C.J., Lion as Slain Lamb: On Reading Revelation Recursively

David W. Haddorff, Can Character Ethics Have Moral Rules and Principles?

Richard C. Bayer, The Coherence of Catholic Social Thought

CREATIVE TEACHING

Terrence Reynolds, Historicism, Truth Claims, and the Teaching of Ethics EDITORIAL ESSAYS

James L. Heft, S.M., and

Leo J. O'Donovan, S.J., A University that Evangelizes? Ex corde ecclesiae Six Years Afterwards

Gerard S. Sloyan, Some Reflections on C.T.S. Beginnings

Leo J. O'Donovan, S.J., Found in God: In Memory of John Carmody

\section{REVIEW SYMPOSIUM}

Denise Lardner Carmody's Christian Feminist Theology:

A Constructive Interpretation

Four Perspectives: Doris Donnelly, Francis J. Buckley, S.J.,

Monika K. Hellwig, Michael H. Barnes

Author's Response: Denise Lardner Carmody

\section{REVIEW ESSAYS}

William M. Shea, Remarks on From the Heart of the American Church

William L. Portier, Spirituality in America: Selected Sources

Plus Reviews of 30 Books

\section{THE JOURNAL OF THE COLLEGE THEOLOGY SOCIETY}

\author{
PUBLISHED AT VILLANOVA UNIVERSITY
}




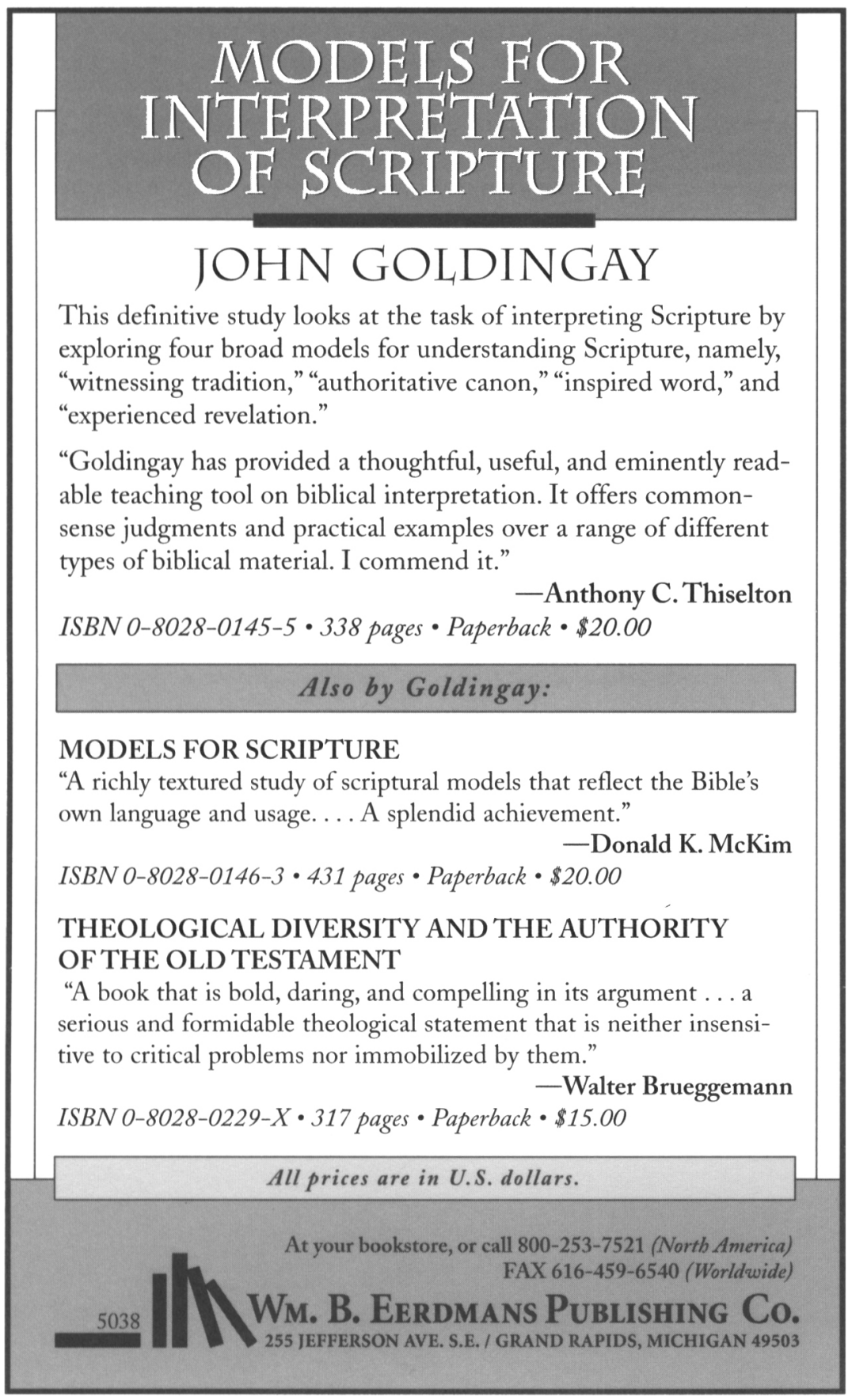




\title{
HORIZONS
}

\section{The Journal of the College Theology Society}

\author{
Published at Villanova University
}

Volume 23

Spring, 1996

Number 1

\section{ARTICLES}

The Infallibility of the Papal Magisterium

as Presented in the Pastoral Letters

of the Bishops of the United States

after Vatican I

Paul K. Hennessy, C.F.C

Lion as Slain Lamb: On Reading

Revelation Recursively Patricia M. McDonald, S.H.C.J.

29

Can Character Ethics Have Moral Rules and Principles? Christian Doctrine

and Comprehensive Moral Theory David W. Haddorff 48

The Coherence of Catholic Social Thought:

Toward a Theology of Involvement Richard C. Bayer

\section{CREATIVE TEACHING}

Historicism, Truth Claims, and the

Teaching of Ethics Terrence Reynolds

\section{EDITORIAL ESSAYS}

A University that Evangelizes?

Ex corde ecclesiae Six

Years Afterwards James L. Heft, S.M., and Leo J. O'Donovan, S.J. 103

Some Reflections on C.T.S. Beginnings Gerard S. Sloyan 113

Found in God: In Memory of John Carmody ....... Leo J. O'Donovan, S.J. 119

\section{REVIEW SYMPOSIUM}

Denise Lardner Carmody's Christian Feminist Theology:

A Constructive Interpretation

Four Perspectives

Doris Donnelly 122

Francis J. Buckley, S.J. 125

Monika K. Hellwig 127

Michael H. Barnes 128

Author's Response Denise Lardner Carmody 131

\section{REVIEW ESSAYS}

Remarks on From the Heart of the

American Church William M. Shea 


\section{BOOK REVIEWS}

Elisabeth Schüssler Fiorenza, ed., Searching the Scriptures, Vol. 1: A Feminist Introduction ... Sandra M. Schneiders 162

Howard Clark Kee, Who Are the People of God? Early Christian Models of Community Pamela Thimmes 163

Gil Baillie, Violence Unveiled: Humanity at the Crossroads Sandra M. Schneiders 164

Tim Dowley, ed., Introduction to the

History of Christianity Joseph Martos

Mary T. Clark, R.S.C.J., Augustine Margaret R. Miles

Rosemary Skinner Keller and Rosemary Radford

Ruether, eds., In Our Own Voices: Four

Centuries of American Women's

Religious Writing

Amanda Porterfield 168

D. G. Hart, Defending the Faith: J. Gresham

Machen and the Crisis of Conservative

Protestantism in Modern America William M. Shea

Patrick G. Coy, ed., Revolution of the Heart:

Essays on the Catholic Worker June O'Connor 170

Paul Mojzes, Yugoslavian Inferno: Ethnoreligious

Warfare in the Balkans Richard Penaskovic

Maryanne Stevens, ed., Reconstructing the Christ

Symbol: Essays in Feminist Christology Michael L. Cook, S.J.

Edward Schillebeeckx and Catharina Halkes,

Mary: Yesterday, Today, Tomorrow Pamela Kirk

Cynthia S. W. Crysdale, ed., Lonergan and Feminism Carla Mae Streeter, O.P. 175

Pope John Paul II, Crossing the

Threshold of Hope Lawrence S. Cunningham 176

R. Bruce Douglass and David Hollenbach, eds.,

Catholicism and Liberalism: Contributions

to American Public Philosophy Paul Misner 177

Paula M. Cooey, Religious Imagination

and the Body: A Feminist Analysis Susan A. Ross 178

Brother Lawrence of the Resurrection, O.C.D.,

Writings and Conversations on the

Practice of the Presence of God Wendy M. Wright

K. C. Abraham and Bernadette Mbuy-Beya, eds.,

Spirituality of the Third World:

A Cry for Life Alfred T. Hennelly, S.J. 180

Michael J. Himes, Doing the Truth in

Love: Conversations about God,

Relationships, and Service Rodger Van Allen 181

J. Philip Wogaman, Christian Ethics:

A Historical Introduction James Gaffney 183 
Pamela M. Hall, Narrative and the Natural Law: An Interpretation of Thomistic Ethics Charles E. Curran 184

David G. Hallman, ed., Ecotheology: Voices from South and North

Patricia Beattie Jung and Ralph F. Smith, Heterosexism: An Ethical Challenge Anthony Battaglia 186

William Reiser, S.J., Love of Learning: Desire for Justice. Undergraduate Education and the Option for the Poor J. J. Mueller, S.J. 188

Roger Arnaldez, Three Messengers for One God Donald J. Dietrich 189

David B. Burrell, C.S.C., Freedom and Creation in Three Traditions Walter H. Principe, C.S.B. 190

Takeuchi Yoshinori, ed., Buddhist Spirituality Vol. 1: Indian, Southeast Asian, Tibetan, and Early Chinese James L. Fredericks 191

Jacob Neusner, ed., World Religions in America: An Introduction William Cenkner 192

Giovanna Borradori, The American Philosopher: Conversations with Quine, Davidson, Putnam, Nozick, Danto, Rorty, Cavell, McIntyre, and Kuhn; John Patrick Diggins, The Promise of Pragmatism: Modernism and the Crisis of Knowledge and Authority William M. Shea 193

BOOKS RECEIVED 197

Copyright (C 1996 College Theology Society

Printed in the United States of America 


\section{HORIZONS}

\section{The Journal of the College Theology Society}

Horizons, The Journal of the College Theology Society is published biannually in Spring and Fall at Villanova University, Villanova, PA 19085.

Yearly subscription: individual $\$ 16.00$, institutional $\$ 40.00$. Send remittance, payable to Wilfrid Laurier University Press, to Wilfrid Laurier University Press, Wilfrid Laurier University, Waterloo, Ontario, Canada N2L 3C5. Changes of address should also be sent to this address. Horizons is automatically received through membership in the College Theology Society.

Manuscripts, editorial and business correspondence, book reviews, advertising copy, and orders for single issues (individual $\$ 8.00$, institutional $\$ 17.00$ ) should be addressed to The Editor, Horizons, Journal of the CTS, Villanova University, Villanova, PA 19085.

In submitting manuscripts, please send four clear copies. Author's name should appear only on an unpaginated cover sheet, with address and essay's title. No other identifying reference to author should appear on the manuscript. All references to author's work in text or notes should be in the third person. Essay's title should appear at top of first page of text. Notes should be placed on separate sheets at end. Full double spacing should be used throughout, including indented quotations and notes. Top, bottom, and right-hand margins should be at least one inch; left-hand margins at least one-and-a-half. Manuscripts should be accompanied by an abstract of one hundred fifty words or less and an author vita of one hundred words or less. Authors should state that the manuscript will not be submitted to another journal until Horizons' evaluation is completed. Manuscripts will be returned if postage is supplied.

Articles appearing in Horizons are abstracted and indexed in: The Catholic Periodical and Literature Index; Guide to Social Science and Religion in Periodical Literature; Index to Religious Periodical Literature; New Testament Abstracts; Religious and Theological Abstracts; and Social Science Citation Index. Articles are indexed in Religion Index One: Periodicals; book reviews indexed in Index to Book Reviews in Religion. Horizons is available in microform from University Microfilms International, 300 North Zeeb Road, Department P.R., Ann Arbor, MI 48106.

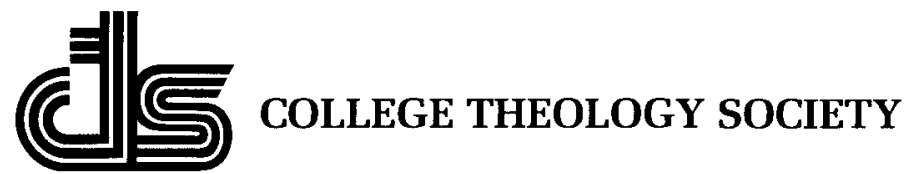

The College Theology Society is a professional organization of college and university professors of religion in the United States and Canada.

The purpose of the College Theology Society is to improve the quality of the teaching of religion: by stimulating and sharing scholarly research; by developing programs of theology and religious studies which meet student needs and interests; and by exploring, evaluating, and encouraging effective ways of teaching which are interdisciplinary and ecumenical.

Annual membership dues in the Society are $\$ 40.00$ (Full Professional or Associate), $\$ 45.00$ (Joint Professional for husband and wife), and $\$ 20.00$ (Graduate Student). Membership in the Society includes a subscription to Horizons. Contact Gary Macy, Theological and Religious Studies Department, University of San Diego, Alcalá Park, San Diego, CA 92110. 


\section{EDITOR}

Walter E. Conn

Villanova University

\section{ASSOCIATE EDITORS}

Lisa Sowle Cahill

Boston College

Denise Lardner Carmody

Santa Clara University

Anne Carr

The University of Chicago

Bernard Cooke

Incarnate Word College

Lawrence S. Cunningham

University of Notre Dame

Charles E. Curran

Southern Methodist University

Elisabeth Schüssler Fiorenza

Harvard Divinity School The Catholic University of America

Francis Schüssler Fiorenza

Harvard Divinity School
Paul F. Knitter

Xavier University

Elena Malits, C.S.C.

Saint Mary's College

Pheme Perkins

Boston College

Norbert J. Rigali, S.J. University of San Diego

Sandra M. Schneiders, I.H.M.

Jesuit School of Theology, Berkeley

William M. Shea

Saint Louis University

Gerard S. Sloyan

William M. Thompson

Duquesne University

Mary Jo Weaver

Indiana University

BOOK REVIEW EDITOR

Joann Wolski Conn

Neumann College

BUSINESS EDITOR

Anne McGuire

Haverford College

EDITORIAL ASSISTANT

Irene C. Noble 


\section{HORIZONS}

\section{The Journal of the College Theology Society}

A journal exploring developments in Catholic theology, the total Christian tradition, human religious experience, and the concerns of creative teaching from the college and university environment.

This issue likely has a little something for everyone-from Papal Infallibility to Spirituality in America. Among the articles, Paul Hennessy examines the presentation of Papal Infallibility by American Bishops after Vatican I, and Patricia McDonald proposes her reading of Revelation in "Lion as Slain Lamb." Then ethicists David Haddorff and Richard Bayer consider Character Ethics and Catholic Social Thought.

History and ethics appear again in Terrence Reynolds' contribution to the Creative Teaching section: "Historicism, Truth Claims, and the Teaching of Ethics." Among our Editorial Essays we have James Heft and Leo O'Donovan on Ex corde ecclesiae, Gerard Sloyan on C.T.S. Beginnings, and Leo O'Donovan remembering Horizons' wonderful friend, John Carmody.

Denise Lardner Carmody's Christian Feminist Theology is the focus of this issue's Review Symposium. Doris Donnelly, Francis Buckley, Monika Hellwig, and Michael Barnes join her in conversation. In Review Essays, William Shea returns us to the meaning of Catholic higher education in David O'Brien's From the Heart of the American Church, an important study first reviewed in these pages by Rodger Van Allen last Fall (22/2). Then William Portier reports on his examination of all twenty-three volumes of sources in Spirituality in America from Paulist Press. Reviews of thirty new books round off the issue. 